\title{
Type 1 deiodinase is stimulated by iodothyronines and involved in thyroid hormone metabolism in human somatomammotroph GX cells
}

\author{
A Baur and J Köhrle \\ Klinische Forschergruppe der Medizinischen Poliklinik der Universität Würzburg, Röntgenring 11, D-97070 Würzburg, Germany \\ (Correspondence should be addressed to J Köhrle, Medizinische Poliklinik, Klinische Forschergruppe, Röntgenring 11, D-97070 Würzburg, Germany)
}

\begin{abstract}
Background: Local 5'-deiodination of L-thyroxine $\left(\mathrm{T}_{4}\right)$ to the active thyroid hormone, 3,3',5-tri-iodothyronine $\left(\mathrm{T}_{3}\right)$ via two deiodinase isoenzymes (D1 and $\mathrm{D} 2$ ) has an important role for various $\mathrm{T}_{3}$-dependent functions in the anterior pituitary. However, no evidence has been presented yet for thyroid hormone inactivation via the 5-deiodinase (D3) in anterior pituitary models.

Methods: Using the human somatomammotroph cell line, GX, we analysed effects of $\mathrm{T}_{3}$ and its $5^{\prime}$ deiodination product, 3,5-di-iodothyronine $\left(3,5-\mathrm{T}_{2}\right)$, on deiodinase activities, measuring release of iodide$125\left({ }^{125} \mathrm{I}^{-}\right)$from phenolic-ring- or tyrosyl-ring-labelled substrates respectively.

Results: $\mathrm{T}_{3}$ and 3,5- $\mathrm{T}_{2}$ rapidly stimulated D1 activity in GX cells in the presence of serum in the culture medium, whereas D2 activity was not detectable under these conditions. However, when the cells were kept under serum-free conditions, specific activity of D2 reached levels similar to those of D1. With tyrosyl-ring labelled 3,5-[ $\left.{ }^{125} \mathrm{I}\right]-, 3^{\prime}-\mathrm{T}_{3}$ as substrate, a significant release of ${ }^{125} \mathrm{I}^{-}$was observed in GX cell homogenates. This is comparable to the D1 activity of liver membranes, which preferentially catalyses 5'-deiodination, but to some extent also 5-deiodination, at the tyrosyl ring.

Conclusions: D1 activity of human GX cells is increased by $\mathrm{T}_{3}$ and $3,5-\mathrm{T}_{2}$. Inactivation of $\mathrm{T}_{3}$ in the anterior pituitary might occur by deiodination at the tyrosyl ring via D1, thus terminating the stimulatory thyroid hormone signal in human somatomammotroph cells.
\end{abstract}

European Journal of Endocrinology 140 367-370

\section{Introduction}

Thyroid hormones regulate various functions of the anterior pituitary (e.g. expression of thyroid-stimulating (TSH) and growth (GH) hormones), that are well characterized in the rat (1). Recently, a human pituitary cell line $(\mathrm{GX})$ has been established that expresses $\mathrm{GH}$ and prolactin mRNA (2). In GX cells, GH mRNA synthesis is stimulated by tri-iodothyronine $\left(\mathrm{T}_{3}\right) . \mathrm{T}_{3}$, the main active form of thyroid hormones, is generated by $5^{\prime}$-deiodination of L-thyroxine $\left(\mathrm{T}_{4}\right)$, the 'prohormone' secreted by the thyroid gland. Two distinct $5^{\prime}$-deiodinases (D1 and D2), which differ in reaction kinetics, substrate specificity, inhibitor sensitivity, and regulation, contribute to systemic and local formation of $\mathrm{T}_{3}$ (3). In the pituitary gland of euthyroid rats, half of the $\mathrm{T}_{3}$ bound to specific nuclear $\mathrm{T}_{3}$-receptors (predominantly TR- $\beta 2$ ) is derived from local, intrapituitary $\mathrm{T}_{4}$-to$\mathrm{T}_{3}$ conversion via deiodinase isoenzymes (4). So far, no evidence has been presented for an inactivation pathway of thyroid hormones via the 5-deiodinase (D3) in anterior pituitary models (5). Recently, we demonstrated that D1 is expressed in rat anterior pituitaries, in reaggregates of rat anterior pituitaries, and in rat somatomammotroph GH3 cells. D1 is stimulated by $\mathrm{T}_{3}$ and its $5^{\prime}$-deiodination product, 3,5di-iodothyronine $\left(3,5-\mathrm{T}_{2}\right)$, and may serve a yet unrecognized, important function within the modulation of thyroid-hormone-dependent genes in the anterior pituitary $(5,6)$. Therefore, we have now examined the expression of D1 and its regulation by thyroid hormones in the human somatomammotroph cell line, GX.

\section{Materials and methods}

\section{Chemicals}

All chemicals were of biochemical or analytical grade. Cell culture media, fetal calf serum, horse serum and antibiotics were purchased from Gibco BRL-Life Technologies $\mathrm{GmbH}$ (Eggenstein, Germany). Additives for the serum-free culture medium and other chemicals were purchased from Boehringer (Mannheim, Germany), Merck (Darmstadt, Germany), Sigma (Munich, Germany) 
and Baker Chemikalien (Gro $\beta$-Gerau, Germany). $3,3^{\prime}, 5^{\prime}-\left[{ }^{125} \mathrm{I}\right]-\mathrm{T}_{3} \quad\left(\mathrm{rT}_{3}\right)$ was purchased from DuPont (Bad Homburg, Germany) and 3,5-[ $\left.{ }^{125} \mathrm{I}\right]-, 3^{\prime}-\mathrm{T}_{3}$ from Formula GmbH (Berlin, Germany). Non-radioactive thyroid hormones and the analogue, $\mathrm{N}$-acetyl-3'-Br,3I, $5^{\prime}-\mathrm{NO}_{2}$-L-thyronine (HB 306), were kindly provided by Dr H Rokos (Henning Berlin, Germany). The purity of $3,5-\mathrm{T}_{2}$ was greater than $99 \%$ and contamination by $\mathrm{T}_{3}$ or $\mathrm{T}_{4}$ was less than $0.1 \%$, as determined by HPLC and thin layer chromatography.

\section{Cell culture}

GX cells (kindly provided by Dr L A Frohmann and Dr R D Kineman) (2) were cultured in $\alpha$ Minimal Essential Medium supplemented with $10 \%$ horse serum and $50 \mu \mathrm{g} / \mathrm{ml}$ gentamicin. Cells were maintained throughout at $37{ }^{\circ} \mathrm{C}$ in an atmosphere of $5 \% \mathrm{CO}_{2}$ and $95 \%$ air saturated with water. For preparation of homogenates, cells were washed once with ice-cold PBS, scraped into ice-cold homogenization buffer $(250 \mathrm{mmol} / \mathrm{l}$ sucrose, $20 \mathrm{mmol} / \mathrm{l} \mathrm{HEPES}, 1 \mathrm{mmol} / \mathrm{l}$ EDTA, $1 \mathrm{mmol} / \mathrm{l}$ dithiothreitol (DTT), pH 7.0) and were sonicated (10 times, $0.5 \mathrm{~s}, 300 \mathrm{~W}$ ).

\section{Biochemical assays}

Specific activities of type 1 and type 2 deiodinase (D1 and D2) were determined in parallel by the release of ${ }^{125} \mathrm{I}^{-}$from $\mathrm{rT}_{3}$ in the absence or presence of $1 \mathrm{mmol} / \mathrm{l}$ 6-n-propyl-2-thiouracil (PTU) using $10 \mathrm{nmol} / \mathrm{l} \mathrm{rT}_{3}$ as substrate and $20 \mathrm{mmol} / \mathrm{l}$ dithiothreitol. The fraction of iodide release blocked by $1 \mathrm{mmol} / \mathrm{l}$ PTU was assigned to D1 and the residual activity not inhibited by PTU was ascribed to D2. 5-Deiodination at the tyrosyl ring was determined by the release of ${ }^{125} \mathrm{I}^{-}$from $3,5-\left[{ }^{125} \mathrm{I}\right]-, 3^{\prime}-\mathrm{T}_{3}$ in the absence or presence of deiodinase inhibitors ( $1 \mathrm{mmol} / \mathrm{l}$ PTU, $10 \mu \mathrm{mol} / \mathrm{l}$ 3-methyl-4',6-dihydroxy$3^{\prime}, 5^{\prime}$-dibromo-flavone (EMD) 21388, $10 \mu \mathrm{mol} / \mathrm{l}$ $\mathrm{HB} 306,10 \mu \mathrm{mol} / \mathrm{l}$ aurothioglucose (ATG), $10 \mu \mathrm{mol} / \mathrm{l}$ iopanoate) using $10 \mathrm{nmol} / \mathrm{l} \mathrm{T}_{3}$ at $\mathrm{pH} 8.0$ in homogenates of GX cells, rat liver microsomes and homogenates of rat brain and placenta. PTU forms covalent intermediates with D1 in its oxidized state and is highly selective for reaction with $\mathrm{D} 1$ rather than with $\mathrm{D} 2$ or D3. ATG is also a potent inhibitor of D1, but also inhibits D2 and D3 to a minor extent. Iopanoate, an iodinated oral X-ray contrast agent, is a potent inhibitor of all deiodinase isoenzymes. The synthetic flavonoid, EMD 21388 , shows conformational similarity to iodothyronine structure and acts by competition with D1 and D2 substrates, but does not inhibit D3 activity (3). HB 306 is a $\mathrm{T}_{4}$ analogue that inhibits D1 and, to some extent, D3 (3). Deiodinase activities were determined in triplicate and expressed as fmol ${ }^{125} \mathrm{I}^{-}$released per min per mg protein. Protein contents of the homogenates were determined by a modified Bradford protein assay (7).

\section{Statistical analysis}

Data were analysed by multiple analysis of variance (ANOVA). When the main effect was significant, the Mann-Whitney U-test was applied post-hoc to determine individual differences between means.

\section{Results}

\section{Effects of $T_{3}$ and 3,5-T, on $5^{\prime}$-D1 activity in $G X$ cells}

In the human somatomammotroph cell line GX, D1 is expressed, whereas D2 activities were not detectable when the cells were cultured in medium containing $10 \%$ horse serum. Incubation with $\mathrm{T}_{3}$ (final concentration $3 \mathrm{nmol} / \mathrm{l}$ ) for $72 \mathrm{~h}$ led to a 2.1 -fold stimulation of D1 activity compared with control. 3,5- $\mathrm{T}_{2}$ at a concentration of $3 \mathrm{nmol} / \mathrm{l}$ had no effect on D1 activity, but greater concentrations significantly increased D1 activity, with a maximum at $30 \mathrm{nmol} / \mathrm{l} 3,5-\mathrm{T}_{2}$ (1.9-fold stimulation over basal levels) (Fig. 1A). An increase in D1 activity was already apparent $6 \mathrm{~h}$ after administration of $30 \mathrm{nmol} / \mathrm{l}$ 3,5-T 2 (Fig. 1B). Basal D1 activities were increased during prolonged cultivation, dependent on cell confluence. When GX cells were kept under serum-free conditions
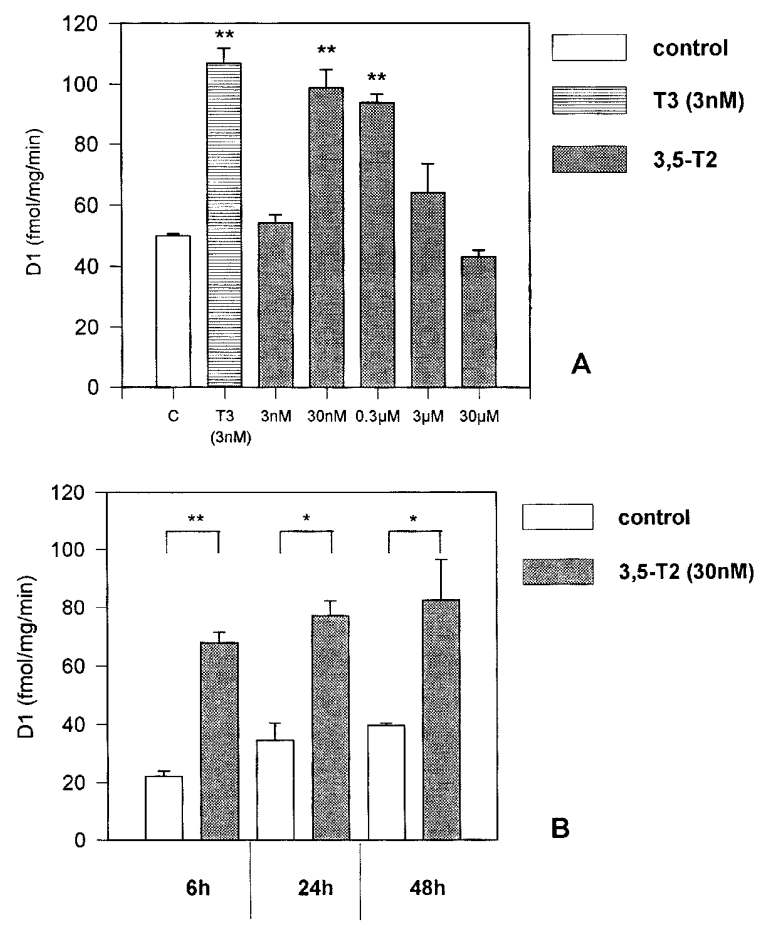

Figure 1 (A) Effects of $T_{3}$ and 3,5-T on D1 activity in the human somatomammotroph cell line, GX, $72 \mathrm{~h}$ after treatment in the presence of $10 \%$ horse serum. Values are means \pm S.E.M. $(n=3)$ of a representative experiment. ${ }^{* *} P<0.005$ compared with control (C). (B) Time course of $3,5-T_{2}(30 \mathrm{nmol} / \mathrm{l})$ stimulation of D1 activity in GX cells in the presence of $10 \%$ horse serum. Values are means \pm S.E.M. $(n=3) .{ }^{*} P<0.05 ;{ }^{* \star} P<0.005$. 
Table 1 Release of ${ }^{125} \mathrm{I}^{-}$from 3,5-[ $\left.{ }^{125} \mathrm{I}\right]-, 3^{\prime}-\mathrm{T}_{3}$ at $\mathrm{pH} 8.0$ by homogenates of GX cells, rat liver, rat brain and rat placenta in the absence (Control, $100 \%$ activity) or presence of deiodinase inhibitors. Values are means \pm S.E.M. $(n=4$, except for brain: $n=1-3)$.

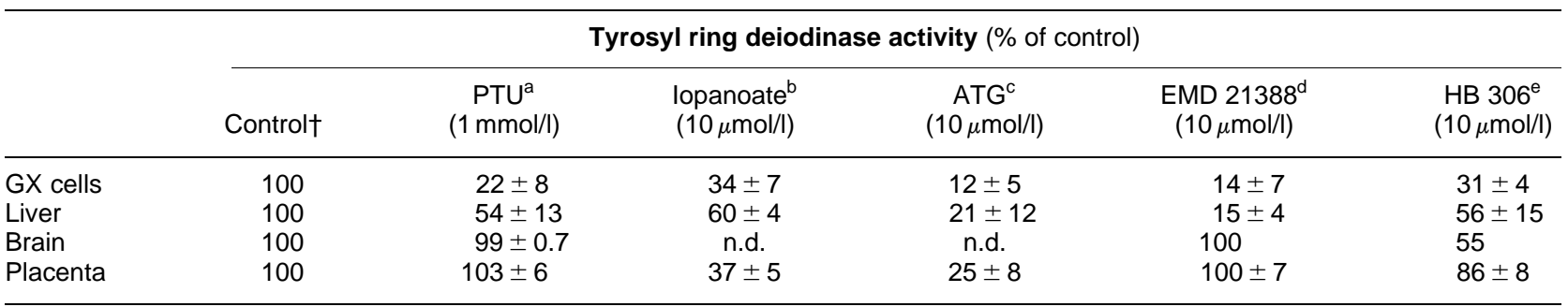

n.d. = Not determined. † Absolute values (fmol/mg/min): GX cells $1.8 \pm 0.2 ;$ liver $23.1 \pm 1.8 ;$ brain $4.2 \pm 1.6 ;$ placenta $27.3 \pm 7.4$.

${ }^{a}$ Selective inhibitor of $\mathrm{D} 1 ;{ }^{b}$ potent inhibitor of all deiodinase isoenzymes; ${ }^{c}$ potent inhibitor of D1, minor effect on D2 and D3; ${ }^{d}$ does not

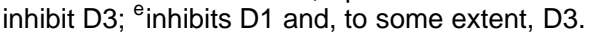

for 3 days, specific D2 activities were measurable and were in a range similar to those of D1 (D1: 18.6 \pm $1.1 \mathrm{fmol} / \mathrm{mg} / \mathrm{min}$; D2: $13.5 \pm 0.9 \mathrm{fmol} / \mathrm{mg} / \mathrm{min})$.

\section{Deiodination at the tyrosyl ring}

With 3,5-[ $\left.{ }^{125} \mathrm{I}\right]-, 3^{\prime}-\mathrm{T}_{3}$ as substrate at $\mathrm{pH} 8.0$, a significant release of ${ }^{125} \mathrm{I}^{-}$was observed in the human GX cells, with reaction characteristics similar to those of the liver D1, which has some 'wobble' at the catalytic site and therefore preferentially catalyses 5'-deiodination, but to some extent also 5-deiodination at the tyrosyl ring (8). The D1 inhibitors PTU, iopanoate, ATG, EMD 21388 and HB 306 blocked the release of ${ }^{125} \mathrm{I}^{-}$from $\mathrm{T}_{3}$ with potencies comparable to those in liver membrane preparations containing D1; there was no evidence for a D3-type 5-deiodination of $\mathrm{T}_{3}$ (Table 1). The marked inhibition of ${ }^{125} \mathrm{I}^{-}$release by PTU and EMD 21388 in GX homogenates indicates that deiodination is catalysed by a D1 activity with some 'wobble' at the catalytic site, similar to the findings in liver, but in contrast to those for brain and placenta, which preferentially exhibit D3 activity at this $\mathrm{pH}$ of incubation.

\section{Discussion}

The effects of thyroid hormones on gene expression in the anterior pituitary of rats have been well studied. Transcription of the TSH genes is suppressed (1) and transcription of the GH gene is increased by $\mathrm{T}_{3}(9,10)$. In both cases thyroid hormone receptors, binding to response elements (negative or positive, respectively) in the promoter regions of these genes, are involved in transcriptional regulation (11). In vivo observations indicated that thyroid hormones exert similar effects on GH secretion in human and in rats $(12,13)$, and Chomczynski et al. (2) demonstrated that $\mathrm{T}_{3}$ stimulated GH gene transcription in the human somatomammotroph GX cell line, not requiring additional serum factors or other hormones. Therefore this cell line provides a good model for investigations of thyroid hormone action in the human pituitary.
In this study, we have demonstrated that deiodinase isoenzymes types 1 and 2 (D1 and D2) are expressed in GX cells and that D1 is stimulated by $\mathrm{T}_{3}$ and $3,5-\mathrm{T}_{2}$. Recently, a complex, positive $\mathrm{T}_{3}$-responsive element has been functionally characterized in the promoter of the human type $15^{\prime}$-deiodinase gene (14). When the cells are cultured in medium containing $10 \%$ horse serum, the activity of D2 is not measurable, but when the cells are kept under serum-free conditions, D2 activities are in a range similar to those of D1, which are lower under these conditions. This may be due to the presence of thyroid hormones in the serum, as pituitary D1 is stimulated and D2 inhibited by thyroid hormones $(3,5)$. Basal activities of D1 increase during culture with increasing cell confluence, implying that cell-cell contacts are involved in D1 stimulation. A similar increase in D1 with increasing confluence is also observed in liver and kidney cell lines (TC Jakobs, A Baur \& J Köhrle, unpublished observations). The stimulating effect of $3,5-\mathrm{T}_{2}$ on D1 activity revealed a bellshaped dose-response curve. This could be due to inactivation of ligands by increased deiodination or other inactivating pathways, such as glucuronidation or sulphation, induced by the greater $3,5-\mathrm{T}_{2}$ concentrations. Recently, we reported that $\mathrm{D} 1$ is rapidly stimulated by $\mathrm{T}_{3}$ and 3,5-T in anterior pituitaries of euthyroid rats, reaggregates of rat anterior pituitaries, and in rat somatomammotroph GH3 cells (6). These observations suggest that D1 serves an important function in regulation of thyroid-hormone-dependent genes in the anterior pituitary and that local para- and autocrine interactions between more abundant somatotrophs and thyrotrophs appear possible.

The demonstration of D1 and D2 in human somatomammotroph GX cells and their regulation by thyroid hormones indicate that similar mechanisms are involved in anterior pituitary regulation in humans. We have now also demonstrated that D1 of GX cells apparently catalyses 5-deiodination of thyroid hormones in a manner similar to that of liver D1, which has some 'wobble' at the catalytic site and therefore might be involved in the inactivation of thyroid hormones, thus terminating the thyroid hormone 
signal. So far, no detailed analysis of expression of deiodinase isozymes in the normal human anterior pituitary is available and only a few cases of deiodinase activity in adenomas have been reported (15). Therefore, extrapolation from the human GX somatomammotroph cell line to the normal or pathophysiological expression of deiodinases and regulation of thyroidhormone-dependent gene expression is not yet possible, and further detailed studies are required. TSH-producing human adenomas are very rare and no other human pituitary cell lines have been established yet. Therefore, this new somatomammotroph human pituitary cell line, which expresses functional deiodinases and responds to $\mathrm{T}_{3}$, is a rather valuable tool with which to further our understanding of the role of local $\mathrm{T}_{3}$ production in human pituitary function.

\section{Acknowledgements}

This work was supported by a grant from the Deutsche Forschungsgemeinschaft (Kö 922/3-1/2).

\section{References}

1 Steinfelder HJ \& Wondisford FE. Thyrotropin (TSH) $\beta$-subunit gene expression - an example for the complex regulation of pituitary hormone genes. Experimental and Clinical Endocrinology and Diabetes 1997105 196-203.

2 Chomczynski P, Soszynski PA \& Frohman LA. Stimulatory effect of thyroid hormone on growth hormone gene expression in a human pituitary cell line. Journal of Clinical Endocrinology and Metabolism 199377 281-285.

3 Leonard L \& Köhrle J. Intracellular pathways of iodothyronine metabolism. In Werner and Ingbar's The Thyroid. A Fundamental and Clinical Text, edn 7, ch 8, pp 125-161. Eds LE Braverman \& RD Utiger. Philadelphia: Lippincott-Raven 1996.

4 Silva JE, Dick TE \& Larsen PR. The contribution of local tissue thyroxine monodeiodination to the nuclear 3,5,3'-triiodothyronine in pituitary, liver and kidney in euthyroid rats. Endocrinology $19781031197-1207$.
5 Köhrle J, Schomburg L, Drescher S, Fekete E \& Bauer K. Rapid stimulation of Type I $5^{\prime}$-deiodinase in rat pituitaries by $3,3^{\prime}, 5$ triiodo-L-thyronine. Molecular and Cellular Endocrinology 1995 108 17-21.

6 Baur A, Bauer K, Jarry H \& Köhrle J. 3,5-Diiodo-L-thyronine stimulates type $15^{\prime}$ deiodinase activity in rat anterior pituitaries in vivo and in reaggregate cultures and $\mathrm{GH} 3$ cells in vitro. Endocrinology 1997138 3242-3248.

7 Bradford MM. A rapid and sensitive method for the quantitation of microgram quantities of protein utilizing the principle of protein-dye binding. Analytical Biochemistry 197672 248254.

8 Toyoda N, Kaptein E, Berry MJ, Harney JW, Larsen PR \& Visser TJ. Structure-activity relationships for thyroid hormone deiodination by mammalian type I iodothyronine deiodinases. Endocrinology $1997138213-219$.

9 Guistina A \& Wehrenberg B. Influence of thyroid hormones on the regulation of growth hormone secretion. European Journal of Endocrinology $1995133646-653$.

10 Maia AL, Harney JW \& Larsen PR. Pituitary cells respond to thyroid hormones by discrete, gene specific pathways. Endocrinology $19951361488-1494$.

11 Muñoz A \& Bernal J. Biological activities of thyroid hormone receptors. European Journal of Endocrinology $1997137433-445$.

12 Davies RR, Dagogo-Jack S, Turner SJ, Kendall-Taylor P, Baylis P, Young $\mathrm{E}$ et al. The effect of thyroid status on growth hormone response to growth hormone releasing hormone 1-44. Journal of Endocrinological Investigations 198912 517-521.

13 Williams T, Maxon H, Thorner MO \& Frohman LA. Blunted growth hormone response to growth hormone-releasing hormone in hypothyroidism resolves in the euthyroid state. Journal of Clinical Endocrinology and Metabolism 198861 454-456.

14 Jakobs TC, Schmutzler C, Meissner J \& Köhrle J. The promoter of the human type I 5'-deiodinase gene. Mapping of the transcription start site and identification of a DR +4 thyroid hormoneresponsive element. European Journal of Biochemistry 1997241 288-297.

15 Itagaki Y, Yoshida K, Ikeda H, Kaise K, Kaise N, Yamamoto M et al. Thyroxine $5^{\prime}$ deiodinase in human anterior pituitary tumors. Journal of Clinical Endocrinology and Metabolism 199071 340344.

Received 9 September 1998

Accepted 18 December 1998 